\title{
Assessment of the Bacterial Pollution and Detection of Antibiotic Resistance Genes in Benin: Case of the Hydrographic Channel Complex Cotonou-Nokoué Lake
}

\author{
Oloufemi Daniel Ichola, ${ }^{1}$ Victorien Tamegnon Dougnon ${ }^{D},{ }^{2}$ Charles Hornel Koudokpon, \\ Alidehou Jerrold Agbankpe $\left(\mathbb{D},{ }^{2}\right.$ Esther Deguenon, ${ }^{2}$ Aime Cezaire Ayena, ${ }^{2}$ \\ and Henri Houenoukpo Soclo \\ ${ }^{1}$ Research and Training Laboratory in Applied Chemistry, Polytechnic School of Abomey-Calavi, University of Abomey-Calavi, \\ Godomey, Benin \\ ${ }^{2}$ Research Unit in Applied Microbiology and Pharmacology of Natural Substances, Polytechnic School of Abomey-Calavi, \\ University of Abomey-Calavi, Godomey, Benin
}

Correspondence should be addressed to Victorien Tamegnon Dougnon; victorien88@hotmail.com

Received 18 December 2020; Revised 9 June 2021; Accepted 28 June 2021; Published 5 July 2021

Academic Editor: Arun S. Kharat

Copyright (c) 2021 Oloufemi Daniel Ichola et al. This is an open access article distributed under the Creative Commons Attribution License, which permits unrestricted use, distribution, and reproduction in any medium, provided the original work is properly cited.

The study aims to document the level of contamination of the aquatic ecosystem of the Cotonou-Lake Nokoué canal hydrographic complex by multidrug-resistant bacteria and their resistance genes. For this purpose, water samples were taken from several points of the complex and from the sediments at the depth of the lake. Samples of several species of freshly caught fish products from the lake were also collected. Bacteriological analyses were carried out according to the AFNOR standard (NF U: 47-100). The identification of the different bacterial species isolated was then carried out using the API 20E gallery and specific biochemical tests. The antibiogram of the strains was performed according to the recommendations of the EUCAST. Molecular characterization of the identified strains was carried out by searching for resistance and virulence genes. The results obtained revealed the presence of several bacterial species in water samples and in sediment and intestine samples of fishery products with a predominance of Gram-negative bacilli. The resistance profile of Gram-negative bacilli showed a total resistance to metronidazole (100\%). $23 \%$ of the strains were also resistant to ciprofloxacin, $41 \%$ to amoxicillin, and $60 \%$ to aztreonam. Of the Gram-positive cocci identified, $66 \%$ was resistant to vancomycin, $7.5 \%$ to ciprofloxacin, $71 \%$ to erythromycin, and $22 \%$ to tetracycline. Regarding the genes sought, $b l a_{\mathrm{TEM}}(46 \%), b l a_{\mathrm{SHV}}(24 \%)$, and $b l a_{\mathrm{CTX}-\mathrm{M}-15}(31 \%)$ were present in the genome of Gram-negative bacilli as resistance genes and fimH (41\%) as virulence gene. As for Gram-positive cocci, the van B gene was completely absent. The van $A$ was present at $6.25 \%$ in Staphylococcus aureus and mecA at 21.88 and $33.33 \%$, respectively, in Staphylococcus aureus and coagulase-negative staphylococci strains. The high resistance of isolated bacterial strains is a matter of concern and calls for a rational use of antibiotics in order to avoid the transmission of antibiotic resistance from the environment to humans.

\section{Introduction}

Antimicrobial resistance has become a public health issue that affects both the environment and public health [1]. For several decades, the world's population has been confronted with serious problems related to water security, which, in order to be useful, must meet certain quality criteria [2]. Water, an important molecule in all sectors, whether in human, animal, or plant health, is vital for a normal life [3].
While certain elements are essential for human health, their accumulation in waters, namely, rivers or lakes, can pose a threat to the ecology and human health [4-6]. Several countries in the world, especially those in the Third World, face serious water quality problems $[7,8]$. Pollution by microorganisms in rivers and lakes is a major concern for the protection of watershed water quality and public health management [9]. Self-medication has contributed heavily to the selection of antibiotic-resistant bacteria [10]. Bacterial 
multidrug resistance to antibiotics remains a major public health problem worldwide, in both developed and developing countries. It causes approximately 700,000 deaths each year from antibiotic-resistant bacterial infections [11]. The aquatic environment is very often the final receptacle of various sources of contaminants from industrial, agricultural, hospital, and urban waste discharges [12]. There is a growing interest in exploring the occurrence of antibiotic resistance genes in the environment and the factors that contribute to their emergence. Aquatic ecosystems provide an ideal setting for the acquisition and spread of resistance genes due to the continuous pollution by antimicrobial compounds from anthropogenic activities [13]. Pollution of rivers by multidrug-resistant bacteria has become a problem that cannot be ignored and raises many questions [12]. A few studies in Benin have focused on microbial contamination of water bodies, but very few have provided information on the resistance genes carried by the bacterial strains isolated in their genome. In order to better understand this current public health problem, the present study therefore sets out to document the level of bacterial contamination of the aquatic ecosystem of the Cotonou-Lake Nokoue channel hydrographic complex and to shed light on a few resistance and virulence genes carried by these bacteria in their genome.

\section{Materials and Methods}

2.1. Study Area and Sample Collection. The study was carried out in southern Benin between $6^{\circ} 25^{\prime} \mathrm{N}$ and $7^{\circ} 30^{\prime} \mathrm{N}$ and covers an area of $17109 \mathrm{~km}^{2}$. The climate is subequatorial, characterized by a bimodal rainfall regime with two rainy seasons alternating with two dry seasons. The average annual temperature is $28^{\circ} \mathrm{C}$, and air humidity varies between $69 \%$ and $97 \%$ [14]. The channel hydrographic complex of Cotonou-Lake Nokoué was the actual study area. The samples collected included water and sediment samples from eleven different points in the lake. Also, samples of freshly caught fish products from the lake were included in the sampling. Figure 1 shows the sampling map.

A total of 20 waters samples, 10 lake bottom sediment samples, and 13 different species of fish products were collected. Figure 2 shows the different species of fish products from Lake Nokoué taken during the collection of samples.

2.2. Bacteriological Analysis of Samples. Bacteriological analyses were carried out according to the AFNOR standard (NF U: 47-100). 2 times $150 \mathrm{ml}$ of the water samples volume underwent membrane filtration with $0.22 \mu \mathrm{m}$ diameter membranes. The both filtration membranes were then recovered on eosin methylene blue (EMB) and Chapman agar plates, respectively. Then, the plates were incubated at $37^{\circ} \mathrm{C}$ for 24 hours.

Each species of fish collected was emptied from the intestines, and $25 \mathrm{~g}$ of intestines of each sample was enriched in $225 \mathrm{ml}$ buffered peptone water (BPW) and incubated for 18 hours at $37^{\circ} \mathrm{C}$. The sediment samples were also enriched with $25 \mathrm{~g}$ introduced into $225 \mathrm{ml}$ of BPW for 24 hours at $37^{\circ} \mathrm{C}$. All broths were inoculated by streak on Chapman and eosin

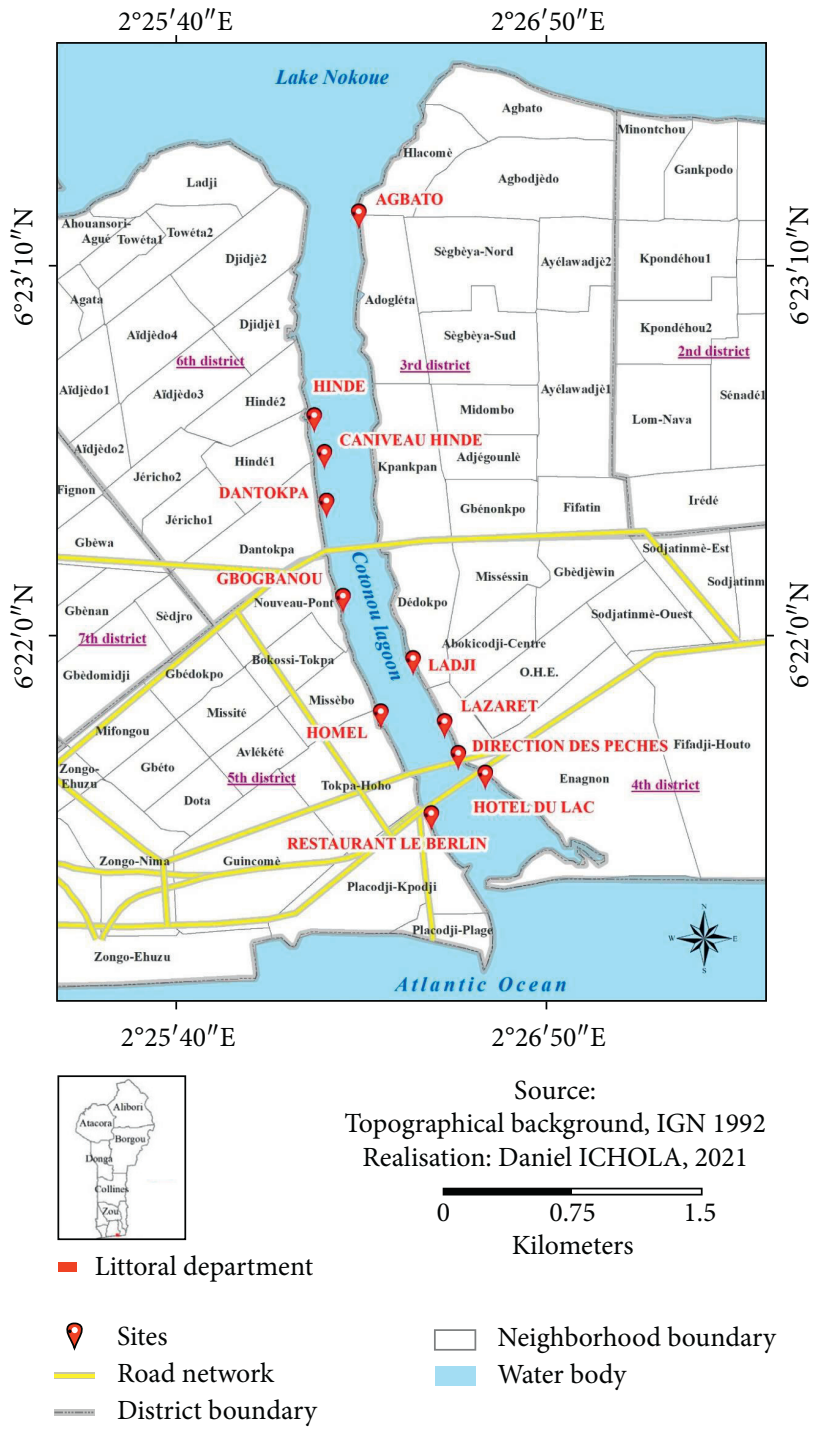

Figure 1: Sample map collection on Lake Nokoué.

methylene blue agar plates for bacterial isolation. These plates were incubated at $37^{\circ} \mathrm{C}$ for 24 hours. Two or three characteristic colonies obtained on the both culture media used were selected. These colonies were streaked on Mueller-Hinton agar plates for purification and then Gram staining, biochemical tests (catalase and oxidase), seeding of the API 20E gallery (for only Gram-negative bacilli), and free staphylocoagulase and DNAse tests (for only Gram-positive cocci).

2.3. Antimicrobial Susceptibility Testing. All identified bacteria were subjected to antimicrobial susceptibility testing on Müller-Hinton agar plates using the Kirby-Bauer disc diffusion method to the following antibiotics: ciprofloxacin $(5 \mu \mathrm{g})$, erythromycin $(15 \mu \mathrm{g})$, tetracycline $(30 \mu \mathrm{g})$, vancomycin $(30 \mu \mathrm{g})$, metronidazole $(5 \mu \mathrm{g})$, amoxicillin $(25 \mu \mathrm{g})$, and aztreonam $(30 \mu \mathrm{g})$. Measured inhibition zone diameters were interpreted according to EUCAST guidelines [15]. The reference strains Escherichia coli ATCC 25922 and Staphylococcus aureus ATCC 25923 were used as a control. 


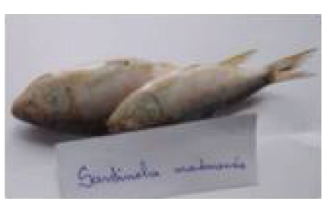

(a)

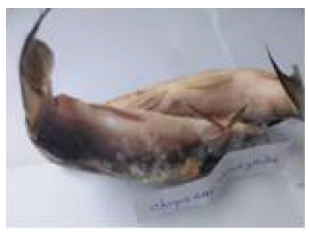

(f)

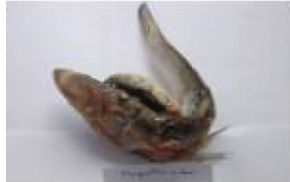

(b)

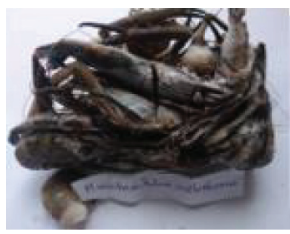

(g)

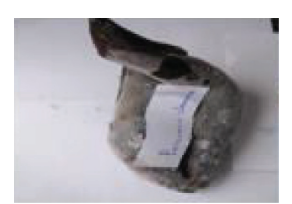

(c)

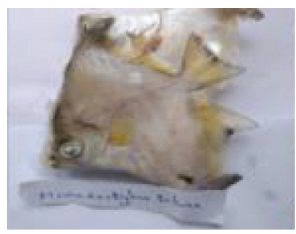

(h)

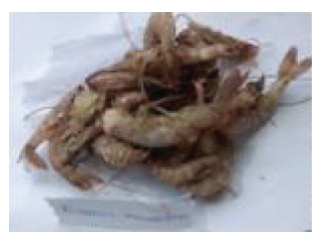

(1)

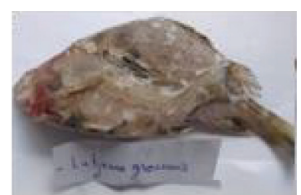

(d)

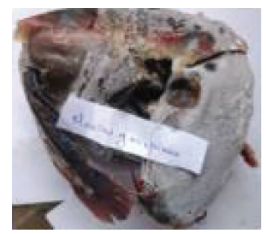

(i)

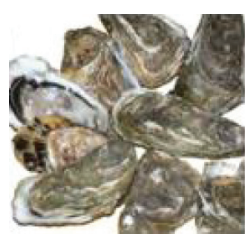

(m)

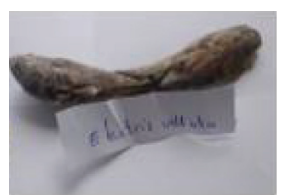

(e)

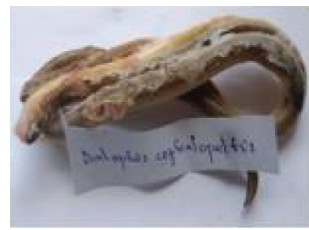

(j)

$(\mathrm{k})$

Figure 2: Different species of fishery products sample. (a) Sardinella madarensis. (b) Hepsetus odoe. (c) Parachanna obscura. (d) Lutjanus groeensis. (e) Eleotris vittata. (f) Chrysichthys nigrodigitatus. (g) Macrobrachium vollenhovenii. (h) Monodactylus sebae. (i) Clarias gariepinus. (j) Dalophis boulengeri. (k) Tilapia guineensis. (l) Penaeus monodon. (m) Crassostrea tulipa.

\subsection{Detection of Resistance and Virulence Genes}

2.4.1. Extraction of DNA from Isolated Strains. The DNA of the Salmonella strains was obtained using the blue Qiagen extraction kit. The tubes containing the DNA were stored at $4^{\circ} \mathrm{C}$ for the amplification phase. The DNA tubes remaining after handling were stored at $-20^{\circ} \mathrm{C}$ for optimal conservation.

2.4.2. Performance of the PCR. The reaction mixture consisted of $7.5 \mu \mathrm{L}$ of water, $12.5 \mu \mathrm{L}$ of the $2 \mathrm{x}$ PCR Master Mix reagent, $2 \mu \mathrm{L}$ of each primer pair, and $3 \mu \mathrm{L}$ of bacterial DNA. Amplification of the $b l a_{\mathrm{TEM}}, b l a_{\mathrm{SHV}}$, and $b l a_{\mathrm{CTX}-\mathrm{M}-15}$ genes was performed under reaction conditions involving initial denaturation at $93^{\circ} \mathrm{C}$ for 4 minutes, followed by 32 cycles at $93^{\circ} \mathrm{C}$ for 30 seconds, $55^{\circ} \mathrm{C}$ for 30 seconds, and $72^{\circ} \mathrm{C}$ for 40 seconds. A final elongation of 4 minutes at $72^{\circ} \mathrm{C}$ was performed. Amplification of the $q n r A$ gene was performed under reaction conditions involving initial denaturation at $95^{\circ} \mathrm{C}$ for 10 minutes, followed by 40 cycles at $95^{\circ} \mathrm{C}$ for 30 seconds, $51^{\circ} \mathrm{C}$ for 30 seconds, and $72^{\circ} \mathrm{C}$ for 15 seconds. A final elongation of 5 minutes at $72^{\circ} \mathrm{C}$ was performed. Amplification of the IMP, KPC, GES, NDM, VIM, OXA-48, OXA-23, and DHA genes was performed under conditions involving initial denaturation at $95^{\circ} \mathrm{C}$ for 5 minutes, followed by 35 cycles at $95^{\circ} \mathrm{C}$ for 20 seconds, $49^{\circ} \mathrm{C}$ for 45 seconds, and $72^{\circ} \mathrm{C}$ for 30 seconds. A final elongation of 5 minutes at $72^{\circ} \mathrm{C}$ was performed. Amplification of the fimH gene was performed under conditions involving initial denaturation at $94^{\circ} \mathrm{C}$ for 2 minutes, followed by 40 cycles of denaturation at $94^{\circ} \mathrm{C}$ for 40 seconds, hybridization at $50^{\circ} \mathrm{C}$ for 1 minute, and initial elongation at $72^{\circ} \mathrm{C}$ for 1 minute. A final elongation was initiated at $72^{\circ} \mathrm{C}$ for 5 minutes. For the PCR of Grampositive cocci, the mecA, van $A$, and van $B$ genes were searched. Amplification was performed under conditions involving initial denaturation at $94^{\circ} \mathrm{C}$ for 4 minutes, followed by 30 cycles at $94^{\circ} \mathrm{C}$ for 1 minute, at $50^{\circ} \mathrm{C}$ for 1 minute, and at $72^{\circ} \mathrm{C}$ for 1 minute. A final elongation of 5 minutes at $72^{\circ} \mathrm{C}$ was performed. The PCR products underwent $2 \%$ agarose gel electrophoresis stained with $5 \mu \mathrm{g} / \mathrm{ml}$ of red gel with a $100 \mathrm{bp}$ DNA ladder as a molecular weight marker. Migration was performed at a scale of $80 \mathrm{~V} / \mathrm{cm}$ for $25 \mathrm{~min}$. The amplification bands were visualized and photographed under ultraviolet light. Table 1 presents the primers of resistance and virulence genes sought.

2.5. Data Processing and Analysis. The data were collected and recorded in an Excel 2010 spreadsheet, and the graphs were created using GraphPad Prism 7 software.

\section{Results}

3.1. Different Bacterial Species Identified. The bacteria identified were mostly enterobacteria followed by Grampositive cocci. Sediment samples contained $40.97 \%$ of the identified bacterial strains followed by water samples (32.63\%) and fish product gut samples (26.38\%). Nonenterobacterial bacilli were identified in $80 \%$ of the sediment samples. Figure 3 presents the different bacteria isolated according to the type of sample. Klebsiella pneumoniae (28.88\%) and Staphylococcus aureus (58.49\%) were the most isolated bacterial strains from all samples collected.

3.2. Resistance Profile of Identified Strains. $35.84 \%$ of the Gram-positive cocci strains identified were multidrug resistant. The greatest resistance was observed to erythromycin 
Table 1: Primers used for the detection of resistance and virulence genes.

\begin{tabular}{|c|c|c|c|}
\hline Genes & Primers & Sequence $5^{\prime}-3^{\prime}$ & References \\
\hline TEM & $\begin{array}{l}\text { TEM F } \\
\text { TEM R }\end{array}$ & $\begin{array}{c}\text { ATGAGTATTCAACATTTCCGC } \\
\text { CAATGCTTAATCAGTGAGG }\end{array}$ & {$[16]$} \\
\hline SHV & $\begin{array}{l}\text { SHV F } \\
\text { SHV R }\end{array}$ & $\begin{array}{l}\text { AAGATCCACTATCGCCAGCAG } \\
\text { ATTCAGTTCCGTTTCCCAGCGG }\end{array}$ & {$[16]$} \\
\hline CTX-M-15 & $\begin{array}{l}\text { CTX-M-15F } \\
\text { CTX-M-15R }\end{array}$ & $\begin{array}{c}\text { CACACGTGGAATTTAGGGACT } \\
\text { GCCGTCTAAGGCGATAAACA }\end{array}$ & {$[16]$} \\
\hline IMP & $\begin{array}{l}\text { IMP F } \\
\text { IMP R }\end{array}$ & $\begin{array}{l}\text { GGAATAGAGTGGCTTAATTC } \\
\text { GGTTTAACAAAACAACCACC }\end{array}$ & {$[17]$} \\
\hline VIM & $\begin{array}{l}\text { VIM F } \\
\text { VIM R }\end{array}$ & $\begin{array}{l}\text { GCACTTCTCGCGGAGATTG } \\
\text { CGACGGTGATGCGTACGTT }\end{array}$ & {$[18]$} \\
\hline GES & $\begin{array}{l}\text { GES F } \\
\text { GES R }\end{array}$ & $\begin{array}{c}\text { GCAATGTGCTCAACGTTCAAG } \\
\text { GTGCCTGAGTCAATTCTTTCAAAG }\end{array}$ & [19] \\
\hline NDM & $\begin{array}{l}\text { NDM F } \\
\text { NDM R }\end{array}$ & $\begin{array}{l}\text { GGCCACACCAGTGACAATATCA } \\
\text { CAGGCAGCCACCAAAAGC }\end{array}$ & {$[20]$} \\
\hline KPC & $\begin{array}{l}\text { KPC F } \\
\text { KPC R }\end{array}$ & $\begin{array}{c}\text { GCCGCCAATTTGTTGCTGAA } \\
\text { GCCGGTCGTGTTTCCCTTT }\end{array}$ & {$[21]$} \\
\hline OXA-48 & $\begin{array}{l}\text { OXA-48F } \\
\text { OXA-48R }\end{array}$ & $\begin{array}{l}\text { TGTTTTTGGTGGCATCGAT } \\
\text { GTAAMRATGCTTGGTTCGG }\end{array}$ & {$[22]$} \\
\hline$q n r A$ & $\begin{array}{l}q n r A \mathrm{~F} \\
q n r A \mathrm{R}\end{array}$ & $\begin{array}{l}\text { AGGATTTCTCACGCCAGGATT } \\
\text { CCGCTTTCAATGAAACTGCAA }\end{array}$ & [23] \\
\hline OXA-23 & $\begin{array}{l}\text { OXA-23 F } \\
\text { OXA-23 R }\end{array}$ & $\begin{array}{c}\text { TTTACTTGCTATGTGGGTTGCT } \\
\text { ATCACCTGATTATGTCCTTGA }\end{array}$ & {$[24]$} \\
\hline van $A$ & $\begin{array}{l}\operatorname{van} A \mathrm{~F} \\
\operatorname{van} A \mathrm{R}\end{array}$ & $\begin{array}{c}\text { GGGCTGTGAGGTCGGTTG } \\
\text { TTCAGTACAATGCGGCCGTTA }\end{array}$ & {$[25]$} \\
\hline van $B$ & $\begin{array}{l}\operatorname{van} B \mathrm{~F} \\
\operatorname{van} B \mathrm{R}\end{array}$ & $\begin{array}{l}\text { TTGTCGGCGAAGTGGATCA } \\
\text { AGCCTTTTTCCGGCTCGTT }\end{array}$ & {$[25]$} \\
\hline mecA & $\begin{array}{l}\operatorname{mec} A \mathrm{~F} \\
\operatorname{mec} A \mathrm{R}\end{array}$ & $\begin{array}{c}\text { TAATTATCGCAGCAGCTGGTTC } \\
\text { GTTCCCAAACGGAGTATAAGAGTG }\end{array}$ & {$[25]$} \\
\hline fimH & $\begin{array}{l}\text { fimH F } \\
\text { fimH R }\end{array}$ & $\begin{array}{c}\text { TACTGCTGATGGGCTGGTC } \\
\text { GGCAATGCTTATTACAGGATGTGC }\end{array}$ & {$[26]$} \\
\hline
\end{tabular}

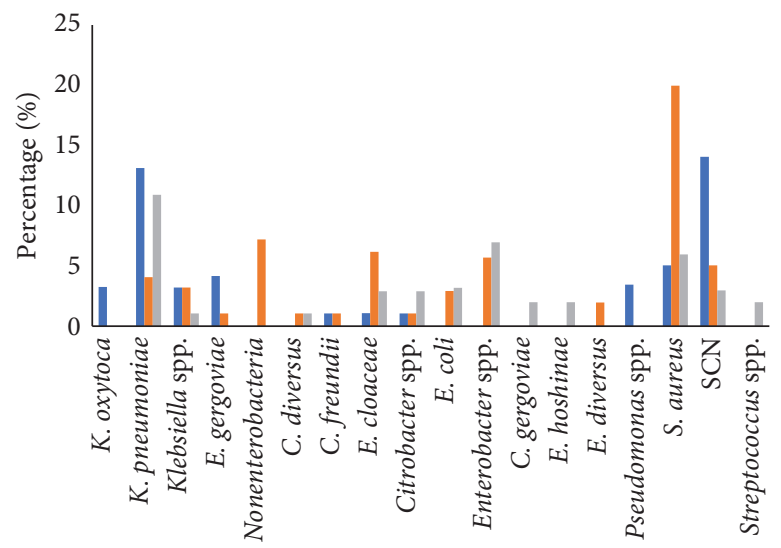

Bacterial species isolated

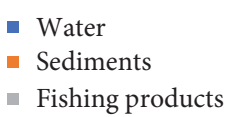

Figure 3: Different bacterial species isolated according to sample type. K. oxytoca, Klebsiella oxytoca; K. pneumoniae, Klebsiella pneumoniae; E. gergoviae, Enterobacter gergoviae; C. diversus, Citrobacter diversus; C. freundii, Citrobacter freundii; E. cloaceae, Enterobacter cloaceae; E. coli, Escherichia coli; C. gergoviae, Citrobacter gergoviae; E. hoshinae, Edwarsiella hoshinae; E. diversus, Enterobacter diversus; S. aureus, Staphylococcus aureus; SCN, coagulase-negative staphylococci. 
(75.47\%), vancomycin (69.81\%), and oxacillin (32.64\%). Figure 4 shows the resistance profile of Gram-positive cocci.

$36.67 \%$ of isolated Gram-negative bacilli were multidrug resistant. All strains were resistant to metronidazole (100\%). $58.89 \%$ resistance was observed to amoxicillin, $40 \%$ to aztreonam, and $23.33 \%$ to ciprofloxacin. Figure 5 shows the resistance profile of Gram-negative bacilli.

3.3. Molecular Characterization of Isolated Bacteria. The van $A$ and $\operatorname{van} B$ genes were tested only in Gram-positive cocci with resistance to vancomycin. As for the mecA gene, it was searched in the genome of all cocci strains and was present in the genome of $25.93 \%$ of the strains. The $\operatorname{van} B$ gene was not found in the genome of any cocci strain unlike van $A$ which was present at $3.70 \%$ (Table 2).

The resistances genes IMP, VIM, NDM, KPC, OXA-48, OXA-23, qnrA, and GES were absent in the genome of all Gram-negative bacilli isolated. The $b l a_{\mathrm{TEM}}$ gene $(45.55 \%)$ was the most found followed by bla $b l a_{\mathrm{SHV}}(23.33 \%)$. Virulence gene $\mathrm{fimH}$ was found in the genome of $40 \%$ of Gram-negative bacilli (Table 3).

\section{Discussion}

The present study was set out to document the level of contamination of the aquatic ecosystem of the Cotonou channel hydrographic complex of Cotonou-Lake Nokoué by antibiotic-resistant bacteria. It should be noted that Lake Nokoué is one of the most important lakes in Benin which allows to satisfy the needs of the populations in fishing products. This study has identified some species of fishery products appreciated and widely consumed by the populations of southern Benin. Among these species, Sardinella madarensis, Hepsetus odoe, Parachanna obscura, Lutjanus groeensis, Eleotris vittata, Chrysichthys nigrodigitatus, Macrobrachium vollenhovenii, Monodactylus sebae, Clarias gariepinus, Dalophis boulengeri, Tilapia guineensis, Penaeus monodon, and Crassostrea tulipa were found among all the fishermen and resellers of these products. These results corroborate those of Niyonkuru and Lalèyè [27] who found the same families and species in their work relating to the impact of a fishing technique on Lake Nokoué. Sediment samples taken from the lake bottom were the most contaminated with bacteria. This could be explained by sedimentation of bacteria in the lake bottom.

The positive search for pathogenic bacteria in the intestines of fishing products represents a high health risk for the people who consume them. Indeed, the bacterial species most found in the intestines of fish products were Klebsiella pneumoniae, Enterobacter spp., Staphylococcus aureus, and Escherichia coli. The work of Novotny et al. [28] has also identified pathogenic bacteria found in fish products that could represent a health risk for human populations. Resistance of all strains of Gram-negative bacilli was found. This result could be due to the fact that this antibiotic is considered as a deworming and antispasmodic agent by Beninese populations and taken without control. It should be noted that

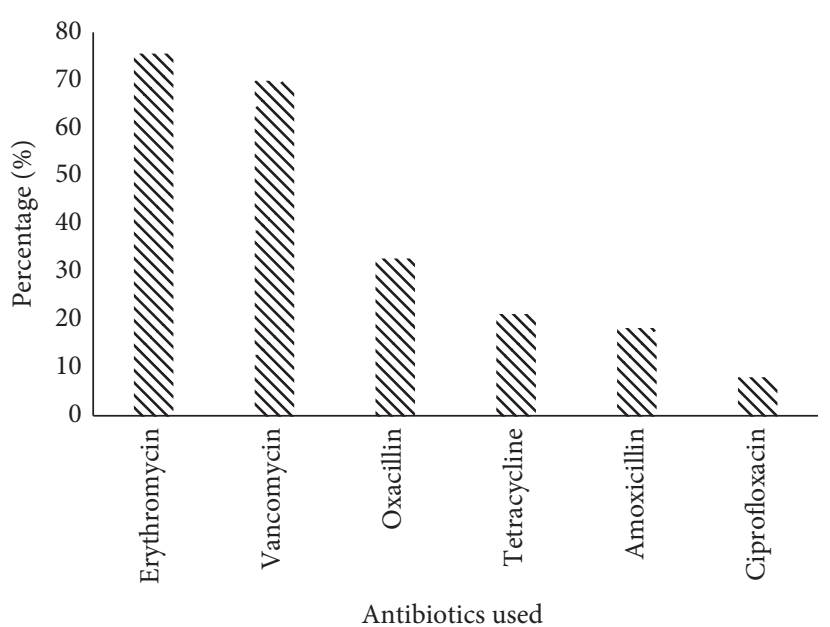

FIGURE 4: Resistance profile of isolated Gram-positive cocci.

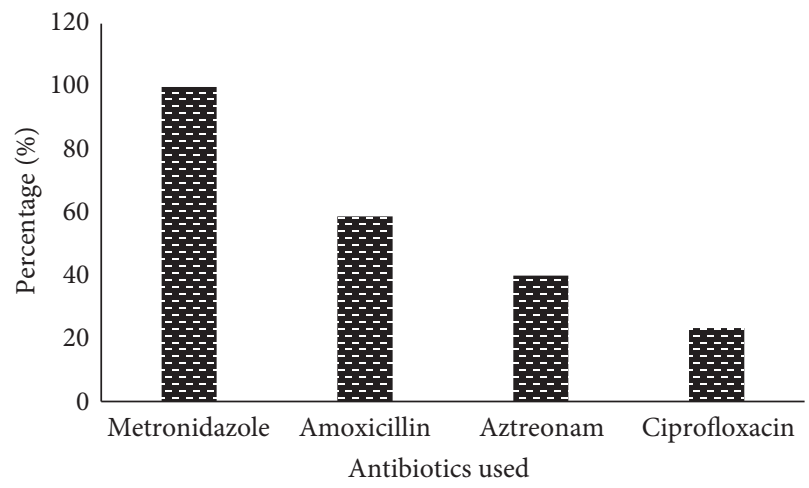

FIGURE 5: Resistance profile of Gram-negative bacilli.

TABLE 2: Resistance genes found in the genome of Gram-positive cocci.

\begin{tabular}{|c|c|c|}
\hline \multirow{2}{*}{ Bacterial strains } & \multicolumn{2}{|c|}{ Resistance genes } \\
\hline & mecA & van $A$ \\
\hline Staphylococcus aureus & $7 / 32(21.88 \%)$ & $02 / 32(6.25 \%)$ \\
\hline SCN & 7/21 (33.33\%) & $0 / 21(0.00 \%)$ \\
\hline Streptococcus spp. & $0 / 1(0.00 \%)$ & $0 / 1(0.00 \%)$ \\
\hline Total & $14 / 54(25.93 \%)$ & $2 / 54(3.70 \%)$ \\
\hline
\end{tabular}

SCN, coagulase-negative staphylococci.

very few studies have reported the use of metronidazole alone in the treatment of infections induced by Gram-negative bacteria. It would thus be judicious to use it in association with other families of antibiotics and according to the infection to hope for better efficacy [29]. Very high resistances of paramount importance in human health were also noted in both Gram-negative bacteria and isolated Gram-positive cocci. Indeed, $40 \%$ of Gram-negative bacteria were resistant to aztreonam, the only monobactam of recourse in case of resistance to carbapenems. Gram-positive cocci were $69.81 \%$ resistant to vancomycin. Associated with these resistances, the $b l a_{\mathrm{TEM}}, b l a_{\mathrm{SHV}}$, and $b l a_{\mathrm{CTX}-\mathrm{M}-15}$ resistance genes were found in the genome of Gram-negative bacilli as well as the fimH 
TABLE 3: Resistance and virulence genes found in the genome of Gram-negative bacilli.

\begin{tabular}{|c|c|c|c|c|}
\hline \multirow{2}{*}{ Bacterial strains } & \multicolumn{3}{|c|}{ Resistance genes } & \multirow{2}{*}{$\begin{array}{l}\text { Virulence gene } \\
\text { fimH }\end{array}$} \\
\hline & $b l a_{\mathrm{TEM}}$ & $b l a_{\mathrm{SHV}}$ & $b l a_{\text {CTX-M-15 }}$ & \\
\hline Pseudomonas spp. & $00 / 02(0 \%)$ & $00 / 02(0 \%)$ & $00 / 02(0 \%)$ & $01 / 02(50 \%)$ \\
\hline Klebsiella oxytoca & 03/03 (100\%) & $02 / 03(66.66 \%)$ & $01 / 03(33.33 \%)$ & 03/03 (100\%) \\
\hline Klebsiella pneumoniae & $13 / 28(46.42 \%)$ & $7 / 28(25 \%)$ & $12 / 28(42.85 \%)$ & $14 / 28(50 \%)$ \\
\hline Klebsiella spp. & 04/07 (57.14\%) & $02 / 07(28.57 \%)$ & $02 / 07(28.57 \%)$ & $03 / 07(42.85 \%)$ \\
\hline Enterobacter gergoviae & 03/05 (60\%) & 03/05 (60\%) & 01/05 (20\%) & 03/05 (60\%) \\
\hline Enterobacter cloaceae & $04 / 10(40 \%)$ & $01 / 10(10 \%)$ & $02 / 10(20 \%)$ & $03 / 10(30 \%)$ \\
\hline Enterobacter diversus & $00 / 01(0 \%)$ & $00 / 01(0 \%)$ & $00 / 01(0 \%)$ & $01 / 01(100 \%)$ \\
\hline Enterobacter spp. & $08 / 12(66.66 \%)$ & $03 / 12(25 \%)$ & $07 / 12(58.33 \%)$ & $04 / 12(33.33 \%)$ \\
\hline Citrobacter diversus & $00 / 01(0 \%)$ & $00 / 01(0 \%)$ & $00 / 01(0 \%)$ & $01 / 01(100 \%)$ \\
\hline Citrobacter freundii & $01 / 02(50 \%)$ & $00 / 02(0 \%)$ & $01 / 02(50 \%)$ & $01 / 02(50 \%)$ \\
\hline Citrobacter gergoviae & 01/01 (100\%) & 01/01 (100\%) & $00 / 01(0 \%)$ & 01/01 (100\%) \\
\hline Citrobacter spp. & $00 / 04(0 \%)$ & $01 / 04(25 \%)$ & $00 / 04(0 \%)$ & $00 / 04(0 \%)$ \\
\hline Escherichia coli & $01 / 05(20 \%)$ & $02 / 05(40 \%)$ & $01 / 05(20 \%)$ & 01/05 (20\%) \\
\hline Edwarsiella hoshinae & $00 / 01(0 \%)$ & $00 / 01(0 \%)$ & $00 / 01(0 \%)$ & $00 / 01(0 \%)$ \\
\hline Nonenterobacteria & 03/08 (37.5\%) & $01 / 08(12.5 \%)$ & $01 / 08(12.5 \%)$ & 00/08 (0\%) \\
\hline Total & $41 / 90$ & $21 / 90$ & $28 / 90$ & $36 / 90$ \\
\hline
\end{tabular}

virulence gene. According to Ruppé et al. [30], the dissemination of plasmid-borne beta-lactamases constitutes by far the most critical resistance problem in Gram-negative bacilli and more specifically in enterobacteria. The dissemination of these genes in the clinic could expose patients to the risk of treatment failure and increased hospitalization time [31]. Several studies have documented the use of extended-spectrum beta-lactamase-producing bacteria [32]. This study is similar to that of Novovic et al. [33] who also isolated Gramnegative bacilli with the $b l a_{\mathrm{SHV}}$ gene from a lake in Bangladesh. The $b l a_{\text {CTX-M-15 }}$ gene is the most widely found CTX$\mathrm{M}$ type ESBL in the world. The $31.11 \%$ prevalence obtained in this study is consistent with Hawkey's work [34] and Canton and Coque [35]. CTX-M-15 has been found predominantly in Escherichia coli but has the ability to rapidly emerge in other Gram-negative bacillus populations [36]. The virulence fim $\mathrm{H}$ gene gives the bacteria carrying it the ability to adhere to cells and escape the action of antibiotics. Countless studies have documented the presence of this gene in the genome of Gramnegative bacilli, notably in Escherichia coli, as in the work of Dadi et al. [37]. In Gram-positive cocci, the mecA gene was the most found followed by van $A$, very little found despite the high resistance observed compared to vancomycin. The presence of the van A gene induces resistance to glycopeptides. The mecA gene indicates the presence of resistance to methicillin [38].

\section{Conclusion}

The data from this study once again raise questions about the appropriate use of antibiotics in agriculture, animal husbandry, and human health in order to prevent multiresistant bacteria from persisting in the environment. The presence of antibiotic-resistant bacteria carrying resistance genes of clinical interest in the aquatic environment is a critical situation that raises fears of an upsurge in infectious diseases that are difficult to treat. This study provides new data on the level of bacteriological contamination of Lake Nokoué in Benin, and given the importance of this aquatic ecosystem, necessary and judicious measures must be taken for an effective depollution of this body of water.

\section{Data Availability}

The data used to support this study are included within the article.

\section{Conflicts of Interest}

The authors declare that they have no conflicts of interest.

\section{References}

[1] R. Sidrach-Cardona and E. Bécares, "Fecal indicator bacteria resistance to antibiotics in experimental constructed wetlands,” Ecological Engineering, vol. 50, pp. 107-111, 2013.

[2] J. Xiao, L. Wang, L. Deng, and Z. Jin, "Characteristics, sources, water quality and health risk assessment of trace elements in river water and well water in the Chinese Loess Plateau," Science of The Total Environment, vol. 650, no. 2, pp. 20042012, 2019.

[3] Z. Chekroud and F. Z. Bouzaouit, "Antibioresistance of bacteria in the rivers of the north east of Algeria (i: case study of saf saf river, the region of elharrouch)," Asian Journal of Microbiology, Biotechnology \& Environmental Sciences, vol. 17, no. 4, pp. 799-808, 2015.

[4] X. Zeng, Y. Liu, S. You et al., "Spatial distribution, health risk assessment and statistical source identification of the trace elements in surface water from the Xiangjiang River, China," Environmental Science and Pollution Research, vol. 22, no. 12, pp. 9400-9412, 2015.

[5] S. Chowdhury, M. A. J. Mazumder, O. Al-Attas, and T. Husain, "Heavy metals in drinking water: occurrences, implications, and future needs in developing countries," Science of The Total Environment, vol. 569-570, pp. 476-488, 2016.

[6] Z. Dong, D. Qin, X. Qin, J. Cui, and S. Kang, "Changes in precipitating snow chemistry with seasonality in the remote Laohugou glacier basin, Western Qilian Mountains," Environmental Science and Pollution Research, vol. 24, no. 12, pp. 11404-11414, 2017. 
[7] P. Chanpiwat and S. Sthiannopkao, "Status of metal levels and their potential sources of contamination in Southeast Asian rivers," Environmental Science and Pollution Research, vol. 21, no. 1, pp. 220-233, 2014.

[8] J. Li, F. Li, Q. Liu, and Y. Zhang, "Trace metal in surface water and groundwater and its transfer in a Yellow River alluvial fan: evidence from isotopes and hydrochemistry," Science of The Total Environment, vol. 472, pp. 979-988, 2014.

[9] C. Chen, A. Kalra, and S. Ahmad, "Hydrologic responses to climate change using downscaled GCM data on a watershed scale," Journal of Water and Climate Change, vol. 10, no. 1, pp. 63-77, 2019.

[10] Y. Titilawo, L. Obi, and A. Okoh, "Antimicrobial resistance determinants of Escherichia coli isolates recovered from some rivers in Osun State, South-Western Nigeria: implications for public health," Science of The Total Environment, vol. 523, pp. 82-94, 2015.

[11] S. Guyomard-Rabenirina, C. Dartron, M. Falord et al., "Resistance to antimicrobial drugs in different surface waters and wastewaters of Guadeloupe," PLoS One, vol. 12, no. 3, pp. 82-94, 2017.

[12] B. O. Abdulsattar, N. A. Al-Saryi, M. H. Abbas, and A.-R. A. Abdulhussein, "Isolation and purification of Escherichia coli bacteriophage from Tigris river, Baghdad, Iraq," Gene Reports, vol. 19, Article ID 100591, 2020.

[13] S. Rodriguez-Mozaz, S. Chamorro, E. Marti et al., "Occurrence of antibiotics and antibiotic resistance genes in hospital and urban wastewaters and their impact on the receiving river," Water Research, vol. 69, pp. 234-242, 2015.

[14] A. Akoegninou, W. J. Van der Burg, and L. J. G. Van der Maesen, Flore Analytique du Bénin, Backhuys Publishers, Leiden, Netherlands, 2006.

[15] The European Committee on Antimicrobial Susceptibility Testing (EUCAST), "Breakpoint tables for interpretation of MICs and zone diameters," Version. 2.0," 2018, http://www. eucast.org.

[16] M. Memariani, S. Najar Peerayeh, T. Zahraei Salehi, and S. K. Shokouhi Mostafavi, "Occurrence of SHV, TEM and CTX-M $\beta$-lactamase genes among enteropathogenic Escherichia coli strains isolated from children with diarrhea," Jundishapur Journal of Microbiology, vol. 8, no. 4, Article ID e15620, 2015.

[17] D. J. Wolter, N. Khalaf, I. E. Robledo et al., "Surveillance of carbapenem-resistant Pseudomonas aeruginosa isolates from Puerto Rican medical center hospitals: dissemination of KPC and IMP-18 $\beta$-lactamases," Antimicrobial Agents and Chemotherapy, vol. 53, no. 4, pp. 1660-1664, 2009.

[18] Y. Li, Q. Guo, P. Wang et al., "Clonal dissemination of extensively drug-resistant Acinetobacter baumannii producing an OXA-23 $\beta$-lactamase at a teaching hospital in Shanghai, China," Journal of Microbiology, Immunology and Infection, vol. 48, no. 1, pp. 101-108, 2015.

[19] Y. Xu, H. Li, R. Shi et al., "Antibiotic resistance genes in different animal manures and their derived organic fertilizer," Environmental Sciences Europe, vol. 32, p. 102, 2020.

[20] F. Wang, R. D. Stedtfeld, O.-S. Kim et al., "Influence of soil characteristics and proximity to antarctic research stations on abundance of antibiotic resistance genes in soils," Environmental Science \& Technology, vol. 50, no. 23, pp. 12621-12629, 2016.

[21] B. M. S. Seco, J. C. Campos, D. A. Da Costa Rocha et al., "Improved blood culture workflow for faster identification of KPC-producing Enterobacterales," Brazilian Journal of Microbiology, vol. 50, no. 1, pp. 127-132, 2019.
[22] J. Monteiro, R. H. Widen, A. C. C. Pignatari, C. Kubasek, and S. Silbert, "Rapid detection of carbapenemase genes by multiplex real-time PCR," Journal of Antimicrobial Chemotherapy, vol. 67, no. 4, pp. 906-909, 2012.

[23] H. Su, X. Hu, L. Wang et al., "Contamination of antibiotic resistance genes (ARGs) in a typical marine aquaculture farm: source tracking of ARGs in reared aquatic organisms," Journal of Environmental Science and Health, Part B, vol. 55, no. 3, pp. 220-229, 2020.

[24] Q. Yang and Y. Rui, “Two multiplex real-time PCR assays to detect and differentiate Acinetobacter baumannii and nonBaumannii Acinetobacter spp. carrying $b l a_{\mathrm{NDM}}, b l a_{\mathrm{OXA}-23-\mathrm{like}}$, $b l a_{\text {OXA-40-like, }} b l a_{\text {OXA-51-like, }}$ and bla $a_{\text {OXA-58-like }}$ genes," PLoS One, vol. 11, no. 7, Article ID e0158958, 2016.

[25] D. Hassan, C. A. Omolo, R. Gannimani et al., "Delivery of novel Vancomycin nanoplexes for combating methicillin resistant Staphylococcus aureus (MRSA) infections," International Journal of Pharmaceutics, vol. 558, pp. 143-156, 2019.

[26] M. M. Gharrah, A. M. El-Mahdy, and R. F. Barwa, "Association between virulence factors and extended spectrum beta-lactamase producing Klebsiella pneumoniae compared to nonproducing isolates," Interdisciplinary Perspectives on Infectious Diseases, vol. 2017, Article ID 7279830, , 2017.

[27] C. Niyonkuru and P. A. Lalèyè, "Impact of acadja fisheries on fish assemblages in Lake Nokoué, Benin, West Africa," Knowledge and Management of Aquatic Ecosystems, vol. 399, no. $5,2010$.

[28] L. Novotny, L. Dvorska, A. Lorencova, V. Beran, and I. Pavlik, "Fish: a potential source of bacterial pathogens for human beings: review Article," Veterinarni Medicina-UZPI (Czech Republic), vol. 49, no. 9, pp. 343-358, 2004.

[29] S. M. Cohn, P. A. Lipsett, T. G. Buchman et al., "Comparison of intravenous/oral ciprofloxacin plus metronidazole versus piperacillin/tazobactam in the treatment of complicated intraabdominal infections," Annals of Surgery, vol. 232, no. 2, pp. 254-262, 2000.

[30] E. Ruppé, P. L. Woerther, and F. Barbier, "Mechanisms of antimicrobial resistance in Gram-negative bacilli," Annals of Intensive Care, vol. 5, no. 1, p. 61, 2015.

[31] P. A. Bradford, "Extended-spectrum $\beta$-lactamases in the 21st century: characterization, epidemiology, and detection of this important resistance threat," Clinical Microbiology Reviews, vol. 14, no. 4, pp. 933-951, 2001.

[32] D. Ojdana, P. Sacha, P. Wieczorek et al., "The occurrence of $b l a_{\mathrm{CTX}-\mathrm{M}}, b l a_{\mathrm{SHV}}$, and $b l a_{\mathrm{TEM}}$ genes in extended-spectrum $\beta$-lactamase-positive strains of Klebsiella pneumoniae, Escherichia coli, and Proteus mirabilis in Poland," International Journal of Antibiotics, vol. 2014, Article ID 935842, 2014.

[33] K. Novovic, B. Filipic, K. Veljovic, J. Begovic, N. Mirkovic, and B. Jovcic, "Environmental waters and $b a_{\mathrm{NDM}-1}$ in Belgrade, Serbia: endemicity questioned," Science of The Total Environment, vol. 511, pp. 393-398, 2015.

[34] P. M. Hawkey, "Prevalence and clonality of extended-spectrum $\beta$-lactamases in Asia," Clinical Microbiology and Infection, vol. 14, no. s1, pp. 159-165, 2008.

[35] R. Cantón and T. M. Coque, "The CTX-M $\beta$-lactamase pandemic," Current Opinion in Microbiology, vol. 9, no. 5, pp. 466-475, 2006.

[36] R. Bonnet, "Growing group of extended-spectrum $\beta$-lactamases: the CTX-M enzymes," Antimicrobial Agents and Chemotherapy, vol. 48, no. 1, pp. 1-14, 2004.

[37] B. R. Dadi, T. Abebe, L. Zhang, A. Mihret, W. Abebe, and W. Amogne, "Distribution of virulence genes and 
phylogenetics of uropathogenic Escherichia coli among urinary tract infection patients in Addis Ababa, Ethiopia," $B M C$ Infectious Diseases, vol. 20, p. 108, 2020.

[38] B. Périchon and P. Courvalin, "VanA-type vancomycin-resistant Staphylococcus aureus," Antimicrobial Agents and Chemotherapy, vol. 53, no. 11, pp. 4580-4587, 2009. 